\title{
CONTEXTUALIZING THE USE OF THE DIPLOMATIC ALTERNATIVE IN CONFLICT RESOLUTION IN THE DISPUTE BETWEEN NIGERIA AND CAMEROON OVER BAKASSI 1994-2006
}

\author{
Ekpotuatin Charles Ariye ${ }^{1}$
}

Laz Etemike ${ }^{2}$

\section{Introduction}

The techniques and Institutions available for resolving international disputes generally fall into the two distinct categories of Judicial and Diplomatic means. Whereas the former involves adjudication and arbitration with the use of special courts and tribunals such as the international court of justice (ICJ), the international criminal court (ICC), international tribunal of the sea e.t.c, the latter is embodied in the instruments of diplomacy, including negotiation, mediation, conciliation, and commissions of inquiry (Menkel-Meadow 2012; Brownlie 2009). In this study, the intent is to bring to light the robust use of the Diplomatic option in arriving at the peaceful and amicable resolution of the Bakassi Peninsula conflict between Nigeria and Cameroon. The work follows a comparative case study structure, using the Nigeria-Cameroon case as a point in understanding better the application and efficacy of alternative measures of dispute resolution. It would be recalled that the ICJ's ruling of 2002 could not alone, finally settle this conflict. Therefore, it becomes important to ascertain what other measures were applied before resolution could be achieved. This will interest discerning observers, who might want

I Department of History, Faculty of Arts and Social Sciences, Isaac Jasper Boro College of Education Sagbama, Yenagoa, Nigeria. E-mail: ariyecharles@yahoo.com

2 Department of Political Science, Faculty of Social Sciences, Novena University, Ogume, Nigeria. E-mail: etemikelaz@yahoo.com 
to have a full and better grasp of the events that led up to the amicable end of this conflict. To this end the work is designed along this line for cohesion and good comprehension; introduction, the theoretical discourse, contextualizing the dispute, ownership claims, adjudication, resolution through alternative means, and finally, the conclusion. Furthermore, it is hinged on the use of secondary source materials, such as books, journal articles, media reports, as well as government papers, with a view towards generating new empirical data on this subject.

\section{The Theoretical Discourse}

According to Brierly ( $\mathrm{Ig}_{3}$ ) the problem of effecting the peaceful settlement of a dispute between two states admits of two alternative methods of approach. He informs that we may either induce the disputing parties to accept terms of settlement which are dictated to them by some third party, or we may persuade them to come together and agree on terms of settlement for themselves. This intellectual argument intersects with the manner of settlement of the territorial conflict between Nigeria and Cameroon over the Bakassi Peninsula between I994 and 2008. Within this period, the dispute passed through several recognized lines of dispute resolution from adjudication through mediation, and to finally a negotiated process of settlement. This last phase of negotiated settlement is of particular interest in the light of the understanding that it came after terms of resolution of the dispute had been handed down to both parties earlier by an impartial arbiter, in this case, the International Court of Justice (ICJ), through its Judgment on the matter of October 2002.

Further discourse on the place and role of diplomacy as an alternative and complementary mechanism in the settlement of disputes has been suggested. For instance, according to Collier (I996), more than ninety-nine percent of international disputes must be settled in the end by negotiation. Similarly, Berridge (2005: I2I-I22) in underscoring the importance of bilateralism says that 'bilateral diplomacy is...relevant in the contemporary world in that usually when negotiations take place, it is much easier on a face to face basis whereby leaders do come together and discuss issues of importance...' In the same vein Allee and Huth (2006) in explaining the merits of bilateralism in dispute resolution offers that the two sides to a dispute have the flexibility to fashion out their desired terms of settlement, and at the same time exercise considerable control over the settlement outcome, by negotiating directly. They add further that in direct negotiations, both sides can also control, at least in part, the information concerning the bargaining process, and the timing of final settlement. 
Vinuales and Bentolila (2012) employ the interaction between judicial and non-judicial means of enforcing investment awards in explaining the diplomatic alternative for dispute resolution. They furnish us with the use of diplomatic exchanges and manoeuvres in the amicable settlement of disputes citing the examples of Aucoven v.Venezuela, where Mexico, the home state of the former, took a number of diplomatic steps to facilitate a peaceful resolution of the dispute through meeting with Venezuelan government officials to work out viable and mutually acceptable modalities for settlement. Other instances referred to where such an approach was applied are given as the Petrobart $v$ The Kyrgz Republic and the Azurix v. CMS cases. Also, Brownlie (2009) in identifying and explaining the varieties of instruments useful apart from adjudication, in the peaceful settlement of international disputes has offered that, the first and classical mode of settlement is negotiation, which involves a direct and bilateral process. Emphasizing its synergy with adjudication, he adds that negotiation can produce a settlement in accordance with legal criteria or with a combination of both legal and political criteria. Like Brownlie, Dinkle (2OII) also characterizes diplomacy as the most ancient form of alternative dispute resolution mechanism. He avers that it involves bringing together parties to a dispute in order to arrive at a meaningful conclusion for both without violence, using negotiation instead of weapons.

On his part Rupesinghe (I995) says that the failings of the rationalist traditional and linear approach to dispute mitigation calls for alternative mechanism. Consequently, he advocates for multi-track diplomacy, which he articulates as a better model to address the underlying causes of modern conflicts, conflicts which he says are more diverse and intra-state in character following the demise of bipolarity in the late I980s. The notion here is that, given that modern conflicts are diffused and multi-layered, mitigation should be designed along several diplomatic tracks. What is clear in Rupesinghe's articulation, despite his cynicism towards linear diplomacy, is that diplomacy, whether linear or multi-track is essential for the construction of a cohesive framework for preventive action and conflict/ dispute resolution. The importance and use of multi-track diplomacy in dispute resolution is also supported by Akin and Brahm (2005). They posit that Third parties in Track I and Track II diplomacy can provide several different roles in the de-escalation of conflicts, by playing the role of mediator, initiate negotiation, generate support for an agreement, and reach and sustain agreements so as to prevent conflicts from occurring.

Carrie Menkel-Meadow (20I2) brings to our understanding the fact that all of the basic and foundational processes of conflict resolution, including negotiation, mediation, arbitration, adjudication, fact-finding, 
conciliation, enquiries, complex multi-party consensus-building, and public policy formation and negotiation have been and are being utilized in ... dispute resolution. She opine that these processes are applied in private, public and hybrid environments of dispute and conflict resolution.

We can discern from the foregoing, a clear understanding of the importance and usefulness of the diplomatic mechanism as a veritable part of the formal dispute resolution process, beside the legal forms of arbitration and adjudication, involving, negotiation, mediation, and the use of Good Offices, forms which were employed prominently in the resolution of this conflict.

\section{Contextualizing the Bakassi Peninsula Dispute}

These two African countries have had troubled relations over the years as a result of differences concerning their common border, especially the 2,300 kilometers land boundary extending from Lake Chad to the Bakassi Peninsula, as well as the maritime aspect located in the Gulf of Guinea. The issues at stake had always been about arriving at a clear and acceptable delineation of the boundary from North to South as well as rights over the oil-rich Bakassi Peninsula and sea reserves, and the fate of local populations along the stretch of the border. On the Bakassi Peninsula, Osita Eze (2007: 2) says that 'the issue of its ownership has been a protracted dispute that had involved several attempts by leaders and representatives of both countries to resolve it.' In the same vein, Ate (I992) offers that 'in one form or the other, the dispute has engaged the attention of almost all Nigerian governments since I960.' Indeed, it is instructive to note that over the years the claims by both countries to the Peninsula have engendered tensions to the extent that in I98I the two countries were almost at the brink of war. This scenario was to play out again in the I990s as Nigerian and Cameroonian troops clashed severally (Baye 20I0) eventually leading to Cameroon's formal application to the ICJ to intervene in I994. This section examines the different dimensions of the events associated with the contentious boundary between the two states, identifying the evolutionary trajectory of the dispute, and outlines the claims of ownership of the Peninsula by both sides prior to when the dispute came before the ICJ for adjudication.

\section{An Appraisal of the numerous arrangements of Bakassi since 1884}

The roots of this dispute are located in the historical European 
imperialistic designs of the igth and 2oth centuries, especially, the colonial enterprises of the Germans, the French and the British. According to Anyu (2007: 4I) the Bakassi Peninsula conflict is one of Africa's throwbacks to the colonial demarcation of the continent'. It would be recalled that the Cameroons was split between Britain and France following its capture from Germany in I9I6, and then subsequently held as a mandate of the League of Nations (Ntamark 2002). Following World War II the Cameroons were administered as Trust Territories of the UN, with a Trusteeship agreement settled in December I946. It has been observed that until I960, both the Northern and Southern Cameroons, were in fact administered as part of Nigeria; the Southern Cameroons as part of the Eastern Region of Nigeria until becoming a semi-autonomous region in I954 and gaining full regional status in 1958, while the Northern Cameroons was governed as part of the Northern Region of Nigeria (Martin 200I: xxxvi).

An appraisal of the numerous arrangements from I884 reveals some legal and pseudo-legal issues. The first is that from the pre-I9I3 agreements, we can discern that the Bakassi Peninsula was administered as part of British possessions. However, going by the I9I3 settlement between Britain and Germany, the area of Bakassi effectively became a German territory. Secondly, Germany, as a result of the war of I9I4 could not take physical control of the Bakassi territory and as such the I9I3 agreement could not be ratified, allowing the British in the event to seize adjoining parts of German territory of Cameroon and administered them as part and parcel of colonial Nigeria up to I960. This scenario has influenced some commentators to opine that the I9I3 Anglo-German Treaty is not binding on Nigeria (Ate I992; Akinjide I994). As a matter of fact, Akinjide who was a Minster of Justice in Nigeria argued that the Anglo-German Treaty was not binding since the Order-in-Council of November 22, I9I3, which came into force on January I, I9I4, amalgamating the Northern and Southern Protectorates into a single Protectorate of Nigeria came into being after the Treaty. Moreover, it is also argued that the Treaty lapsed with the War and that under the terms of the Versailles settlement as provided for in Article 289 , Britain ought to have made effort to revive pre-war bilateral Treaties with Germany, since Britain took no steps to do so then in the terminology of Article 289 it was and remained abrogated, and therefore Cameroon could not succeed to the Treaty (Eze 2007). As plausible as these arguments may sound, the fact of the principle of Uti Possidetis, in International Law, which relates to the sanctity of colonial boundaries, a principle which the OAU (AU) Charter adopted in I963 suggests that Cameroon has a right to succeed to the treaty, especially when considered against the understanding that France, with its League and UN investitures, agreed other settlements 
with Britain after the two wars, and remained as the Colonial Master, not Germany, of Cameroon up to her independence. We now take this general understanding of the colonial attributes of the dispute to examine the various claims to the territory by Nigeria and Cameroon.

For Nigeria, she premised her claim to the territory largely on the various Anglo-German correspondences (Exchange of Notes) of the I88os, as well as the Treaties of protection between the British and the indigenous Kings and Chiefs of the area. Nigeria argued that the legal situation at the time of her independence in I960 from Britain was such that, she inherited the original title of Bakassi which was vested in the Kings and Chiefs of Old Calabar and that this title was not affected by the Anglo-German Treaty of March II, I9I3. According to Ofonagoro (2013), this view by Nigeria was anchored on the notion that the I884 Treaty of Protection between Britain and the King and Chiefs of Old Calabar did not entitle the British Monarch to alienate the territory of the Efik (indigenous) Kingdom, without the approval of the Efik King and Chiefs as landowners. Summer (2004) captures Nigeria's four points claim to title over the peninsula:

I. Long occupation by Nigeria and by Nigerian nationals constituting an historical consolidation of title and conforming to the original title of the Kings and Chiefs of Old Calabar which became vested in Nigeria at the time of independence.

2. Effective administration by Nigeria, acting as Sovereign, and an absence of protest.

3. Manifestations of Sovereignty by Nigeria together with the acquiescence by Cameroon to Nigerian Sovereignty over the Bakassi Peninsula.

\section{Recognition of Nigerian Sovereignty by Cameroon}

Conversely, Cameroon predicated her claim mainly on the AngloGerman Treaty of I9I3 which defined the spheres of control in the area between the two colonial powers. She also hinged her basis on two agreements signed in the I970 that she had with Nigeria in the form of the Yaounde II Declaration of April 4, I97I, and the Maroua Declaration of June I, I975 (Ate I992: I52-I62). These arrangements were devised to outline the maritime boundary between the two countries. The settlement line was drawn through the Cross River estuary to the West of the peninsula, effectively placing Bakassi on Cameroonian territory. Ofonagoro (2013) sums up the Cameroonian basis of claim on these grounds: 
I. The Anglo-German Agreement of March II, I9I3, relating to the settlement of their Colonial Frontier between Yola and the Sea and the Regulation of Navigation on the Cross River.

2. The Anglo-German Agreement of April I2, I9I3 regarding the boundary of Nigeria and Cameroon from Yola to the Sea.

3. The Yaounde II Declaration of April 4, I97I, following that of Yaounde I of August I4, I970.

4. The Lagos Declaration of June 2I, I97I.

5. The Kano Declaration of September I, I974 delimiting a 4-kilometre buffer corridor, i.e. 2 kilometres on either side of the line joining Fairway landing buoy to buoys No. I, 2 and 3 of the Calabar Channel.

6. The Maroua Declaration of June I, I975, which extends the course of the Boundary from point $\mathrm{i} 2$ to point $\mathrm{G}$.

The foregoing represents the general claims that both countries relied on as Cameroon instituted litigation at the International Court of Justice, in the process submitting its entire set of border-related disputes with Nigeria before the World Court for adjudication.

\section{The failure of Adjudication}

Matters between Nigeria and Cameron came to a head over the peninsula in 1993 when Nigerian troops entered and occupied the area. Following a series of further border incursions that provoked shootings from both sides in the process resulting in casualties and deaths recorded on each side. Cameroon formally on March 24, I994 instituted a suit against Nigeria at the International Court of Justice, at the Hague, seeking an injunction for the expulsion of Nigerian troops, which it said were occupying its territory and to restrain Nigeria from laying claim to Sovereignty over the Peninsula (Aghemelo and Ibhasebhor 2006).

Both countries agreed and accepted the compulsory jurisdiction of the ICJ in line with the provisions of the Statute of the Court as outlined in Article 36 , which states inter-alia in paragraph 2 that 'the states parties to the present Statute may at any time declare that they recognize as compulsory ipso facto and without special agreement, in relation to any other state accepting the same obligation, the jurisdiction of the Court in all legal disputes...' (www.icj-cij.org). Before the Court both parties made arguments based on treaties, history, effective control, as well as Uti Possidetis (Sumner 2004). Indeed in their respective final presentations before the 
Court, Cameroon on her part asked for the following prayers: that the land boundary between Cameroon and Nigeria was determined by the AngloGerman Agreement of March II, I9I3; that in consequence, sovereignty over the Bakassi Peninsula is Cameroonian. Conversely, Nigeria requested the Court to adjudicate and declare that 'sovereignty over the Peninsula is vested in the Federal Republic of Nigeria; and that Nigeria's sovereignty over Bakassi extends up to the boundary with Cameroon (THISDAY Nigerian Newspaper 2002).

Following a little over eight years of examining the matter, the ICJ delivered judgment on October IO, 2002, deciding that the very important issue of sovereignty over the Bakassi Peninsula rested with Cameroon and not Nigeria. The Court hinged her decision on the same old colonial agreements and settlements between Britain and Germany (Lacey and Banerjee 2002). Consequently, the Court directed Nigeria to withdraw all administrative, police and military personnel unconditionally from Cameroonian territory including the Bakassi Peninsula. It equally requested Cameroon to do likewise along the land boundary from Lake Chad to the Bakassi Peninsula on areas which pursuant to the judgment were under the sovereignty of Nigeria (Baye 20I0). Furthermore, the Court settled the land boundaries between the two countries from Lake Chad in the North to Bakassi in the South. However Bekker (2003) says that the Court could not specify an actual location of their maritime boundary off the Coast of Equatorial Guinea.

\section{Responses to the ICJ's Ruling}

The Court's decision satisfied the prayers of Cameroon for sovereignty over Bakassi, so naturally, it was Nigeria that had a reason to question and raise objections to the judgment. The emergent scenario was one of domestic reluctance from both the government and informed public opinion to accept the decision. The implication of the judgment clearly is that Nigeria had lost the territory completely to Cameroon. Consequently, the immediate reaction was that Nigeria rejected the ruling with a rhetoric that could apparently suggest recourse to war to hold on to the territory (Friends of the Earth 2003). Indeed, in an official government statement days after the judgment, Nigeria according to Llamzon (2007) appeared to accept aspects of the Court's decision it considered favourable, and rejected other parts it felt uncomfortable with. The government of President Obasanjo pleaded Nigeria's constitutional provisions as a federal state as a case for non-compliance. The argument was that since all land and territorial makeup of the country is specified in the constitution, then the federal (central) government alone can not give up the Bakassi territory without 
the necessary inputs from the state and national assemblies to amend the constitution (Africa News Service 2003). In explaining this position, President Obasanjo says thus 'we want peace, but the interest of Nigeria will not be sacrificed.... What may be legally right may not be politically expedient' (Vanguard Nigerian Newspaper 2002).

Clearly, Nigeria's position on the judgment was an ambivalent one of deliberate indifference where she neither wholeheartedly accepted nor rejected the decision of the Court. In the official statement of the government released via the office of the special assistant to the president on National Orientation and Public Affairs, the summary states as follows:

'Having studied the judgement as entered by the Court, it is apparent that a lot of fundamental facts were not taken into consideration in arriving at their declaration. Most disturbing of these being the difficulties arising from the Orders contained in the judgement, particularly, the Order relating to Nigerian communities in which their ancestral homes were adjudged to be in Cameroonian Territory but which are expected to maintain cultural, trade and religious affiliations with their kith and kin in Nigeria. Nigeria takes cognizance of these serious implications and therefore appeals to all her citizens at home and abroad to remain calm, positive and constructive until we can find a peaceful solution to the boundary issue between Nigeria and Cameroon. We appreciate and thank the Secretary General of the United Nations for brokering meeting at the highest political level between Nigeria and Cameroon before the judgement was delivered and for offering his good offices to broker a similar meeting now that the judgement has been delivered with a view to effecting reconciliation, normalization of relations and good neighborliness. Nigeria thanks all leaders of the international community who have expressed concern over the issue and re-assures them that she will spare no efforts to maintain peace between Nigeria and Cameroon and indeed in the entire region. However, Government wishes to assure Nigerians of its constitutional commitment to protect its citizenry. On no account will Nigeria abandon her people and their interests. For Nigeria, it is not a matter of oil or natural resources on land or in coastal waters; it is a matter of the welfare and well-being of her people on their land. We assure the people of Bakassi and all other communities similarly affected by the judgement of the International Court of Justice on the support and solidarity of all other Nigerians. Nigeria will do everything possible to maintain peace in Bakassi or any other part of the border with Cameroon and will continue to avail itself of the good office of the Secretary-General of the United Nation and other well meaning leaders of the International community to achieve peace and to maintain harmony and good neighborliness' (The Guardian Nigerian Newspaper 2002).

This veiled threat to reject the judgment by the government of Nigeria resonated further in some aspects of the population. We could discern that post judgment rhetoric from informed public commentators 
was troubling and recalcitrant, coupled with internal political pressures on the government not to respect the Court's decision (Asobie 2003). The general picture was one in which such forces called on the government not to consider handing over the territory to Cameroon under any guise, arguing that historical antecedents and long period of occupation warrants Nigeria to hold on to the territory (Okoh 2006). This recalcitrant position of Nigeria was worrisome when considered against an earlier agreement between the leaders of the two countries before the judgment of October IO, 2002. Llamzon (2007) informs that President Biya of Cameroon reported that he and President Obasanjo had an understanding to accept the judgment of the Court in a meeting with UN Secretary-General Kofi Annan on September 5 2002. This position is clearly supported by a UN press statement to that effect even though Nigeria denied the existent of any such agreement (UN Press Release 2002). Generally, Cameroon took Nigeria's stance with relative calm, with her minister for communication, Jacques Ndongo calling on his countrymen to absorb the reaction of Nigeria to the ruling with 'calm, dignity and serenity' (Cameroon Television (CRTV) Online 2002).

On the whole, this was the general scenario following the judgment of the Court on October 2002. Nigeria was expected to comply and quickly set in motion the machinery for ceding the territory to Cameroon as directed by the Court. However, the domestic constrains identified earlier prevented the leadership of the day to act as expected, so that it was left for the international community and other peace loving and well meaning bodies to broker further interactions and understandings between the two countries. Conflict, it is claimed can neither be positive nor negative; rather, it is the response of the parties involved that determines its outcome. In this case, there was therefore the need to allow for diplomatic means to resolve the deadlock (see Adedayo 2013: 59). This is where the alternative means becomes imperative in resolving conflict.

\section{Resolution through Alternative Means}

We can recall that the good offices role of the UN SecretaryGeneral had been put to use even before the judgment of October 2002 . This was applied further after the judgment to make the parties to agree on an implementation plan that will facilitate an acceptable and amicable settlement. Meanwhile, following Nigeria's ambivalence toward the Court's decision, the international community developed interest in seeing to the compliance of the ICJ's judgment. This display of naked defiance by Nigeria prompted fears from many quarters that enforcing the ruling may present 
glitches (Anyu 2007). As a result, the United States, France and Britain, all, exerted diplomatic pressures on Nigeria to abide by the ruling of the Court. Britain in particular through her High Commissioner to Nigeria buttressed the fact that 'ICJ judgments are binding and not subject to appeal, so that Nigeria has an obligation under the United Nations Charter to comply with the judgment' (Agence France-Presse 2002). In the same vein, the British Foreign Minister for Africa met with the Nigerian Ambassador to remind him of President Obasanjo's earlier promise to abide by the Court's ruling (Llamzon 2007).

In subsequent years, the United Nations and its Secretary-General became the pivot around which the settlement efforts were revolved, thus, easing tension and renewing brotherly relations between Nigeria and Cameroon. Following the judgment, a series of bilateral meetings brokered by the UN were held between both parties from which both countries requested for a UN Joint Commission to be established to look at all possible implications of the ruling. Under the auspices of the Secretary-General's good offices role, the first of such achievements was on November I5, 2002 in Geneva when both Presidents in a joint communiqué agreed not only to the setting up of their Mixed Commission, but also 'to consider ways of following up on the ICJ ruling and moving the process forward' (Eze 2007), protect the rights of the people in the affected areas, and propose a workable solution (Llamzon 2007). Again, on January 3I, 2004, after a Tripartite Summit in Geneva, both Presidents Biya and Obasanjo, and the Secretary-General issued a joint communiqué, in which they adopted a comprehensive settlement plan up to 2005 . This progressive plan also involved the smooth and gradual withdrawal of all civilian, military and police forces from affected areas. Furthermore, the UN Secretary-General called on the international community to provide assistance within the purview of preventive diplomacy for the bilateral efforts of the two countries, particularly, funds for boundary demarcation and confidence building measures (Eze 2007). Indeed, the Mixed Commission and the Greentree Agreement of 2006 acting as alternative dispute resolution mechanisms engendered lasting reconciliation and peace between the two disputing countries.

\section{The Mixed Commission}

As noted above it is at the behest of the two countries that the Mixed Commission came into being. Chaired by a Special Representative of the UN Secretary-General, Ahmedou Ould-Abdallah, the Mixed Commission met eighteen times between 2002 and 2007 every two months on an alternating basis in Abuja and Yaounde comprising delegations from both 
parties and with the following as its mandate: the demarcation of the land boundary between the two countries; the withdrawal of civil administration, military and police forces and transfer of authority in relevant areas along the boundary; the eventual demilitarization of the Bakassi peninsula; the need to protect the rights of the affected populations in both countries; the development of projects to promote joint economic ventures and crossborder cooperation; and the reactivation of the Lake Chad Basin Commission (Baye 20I0 ). To achieve this set mandate, the Commission went further to establish sub commissions and working groups made up of experts from both countries and the United Nations covering the following areas of, boundary demarcation including maritime; population; civil administration and police forces; as well as complete withdrawal and transfer of authority in the Bakassi Peninsula (Eze 2007).

The first task of the Mixed Commission was the demarcation of the land boundary between the two countries from the North to the South. To this end in 2003 it embarked on field visits to the Land boundary, the Lake Chad area, and the Bakassi Peninsula. By January 2004, the working group on the withdrawal of civilian, military and police forces completed its assignment and effected transfer of authority in the Lake Chad area to Cameroon. In this same spirit, the process of disengagement and handover of authority as stipulated in the Court's judgment was implemented with respect to other contested areas of their boundary. Both states, employing a give and take format, traded villages across their long mutual border in 2004, and 2006 (The Tide Online Nigerian Newspaper 2006). Indeed in a public statement through her National Boundary Commission, Nigeria affirmed the resolve by both parties to implement the decision on the Lake Chad Region, the land boundary from the lake to the sea and their maritime boundary. The statement further added that field work on the land boundary, including mapping and identification of pillars in accordance with the decision was also being implemented (Llamzon 2007).

On the aspect of joint economic cross-border cooperation, the Mixed Commission monitored the construction of border markets and roads linking the two countries. However, in as much as all appeared smooth sailing and on track, the thorny issue of the oil-rich Bakassi could not be resolved timely and amicably like the other areas. According to Borzello (2004), Nigeria could not respect two disengagement timetables set out by the Commission, as thousands of Nigerians in the Peninsula were disillusioned, unsure of their citizenship with many wanting to remain Nigerians due to their cultural and economic ties with the country. So that by January 2006, the Bakassi Peninsula was still under Nigerian control with Nigeria putting forward arguments that her withdrawal would lead to the 
breakdown of law and order. Additionally, Nigeria proposed a referendum to decide the sovereignty of the peninsula since the people on the Peninsula prefer to remain in Nigeria (Eboh 2005).

This logjam over Bakassi's sovereignty became a source of great concern probably due to its rich hydrocarbon resources. As a matter of fact, strong internal opposition towards relinquishing the area to Cameroon increased in Nigeria. The Tide Online (2006) reported that there were calls on the government of Obasanjo to go to war, with this school of Nigerians arguing that it is against the national interest of the country with regard to security and economic considerations to abide by the Court's decision in its entirety. Interestingly anti-war proponents cautioned against the calls for war, pointing out the consequences of such an action on women, children and youths in general (Asobie 2003). Furthermore, they offered that 'the principle of good faith' in international relations demands that Nigeria should adhere to the ICJ's judgment and respect her words of honour embedded in the Diplomatic Notes of 1962 (Aghemelo and Ibhasebhor 2006). This was the general state of events following the work of the Mixed Commission which led to the peaceful settlement of other aspects of the boundaries between the two parties. With sovereignty over Bakassi still unresolved, it took intensive mediation efforts by the UN Secretary-General Kofi Annan to bring the two parties together to set out a comprehensive agreement in consonance with the ICJ's ruling.

\section{The Greentree Agreement as basis for final resolution}

Brokered by the UN Secretary General and witnessed by Britain, France, Germany, and the United States, this last comprehensive agreement came out of a summit in June 2006 at Greentree, United States of America. Its task was to work out modalities for the withdrawal of Nigerian troops and transfer authority to Cameroon (Gambari 2007). Under its general terms, Nigerian troops are to withdraw within a time frame of ninety days, while a transition period of two years provided for Cameroonian administration to take over from Nigerians. It also provided for Nigerians living in the Peninsula to remain there under a special arrangement for four years after which Cameroon takes over full control. It became the basis for final resolution of the Nigeria-Cameroon dispute over the Bakassi Peninsula and formally put an end to a tricky and tempestuous series of events that had all the hallmarks of potentially degenerating into an all out war situation. Commenting on the significance of this arrangement, Kofi Annan observes that 'with today's Agreement... a comprehensive resolution of the dispute is within our grasp; the momentum achieved must be sustained' (UN Press Release 2006). 
This Agreement as the basis for the final resolution of the dispute and the decisive point of compliance to the ICJs ruling of 2002 ensued that by I August 2006 according to the BBC, Nigeria began withdrawing her about 3,000 troops from the area in line with the provisions of this settlement to pull out troops within 90 days. This move by Nigeria set the pace for Cameroon to subsequently send in her civil administration and regain the peninsula (The Washington Times 2006). However, a face saving measure in the agreement made provision for a time table for complete and final hand over in June 2008, allowing for Nigeria to maintain its presence in 18 percent of the area from 2006 to 2008 , and on the part of Cameroon, she was to follow a code of conduct for the treatment of the local Nigerian population pending their resettlement (This Day Nigerian Newspaper 2006). This fourteen years quest for peaceful resolution of this border dispute between Nigeria and Cameroon climaxed on I4 August 2008 with the Treaty of Calabar between the two which marked the total pull out of all forms of Nigeria's civilian and police forces from the Bakassi Peninsula as enshrined in the Greentree settlement.

\section{Conclusion}

With regard to the territorial dispute between Nigeria and Cameroon, what we see is the application of diplomatic mechanisms for final resolution based on the ruling of the ICJ, a ruling which in itself could not yield instant settlement. As such, as a means of moving forward the process of resolution along the lines of the judgment, the diplomatic approach had to be adopted. It proved successful in bringing together the parties under a bilateral umbrella brokered by a third party, and making them to agree to mutually acceptable terms of final resolution.

It must be emphasized that alternative dispute resolution mechanism is a standout mechanism for paecebuilding. According to Lederachi (I995:I9) (quoted by Adedayo 2013: 52) paecebuilding is a concept that encompasses or generates and sustains the full array of processes, approaches and stages that can transform conflict situations towards sustainable peace attainment. This supports the view that it is difficult to have a single analysis for the trends of international conflict prevention. We could thus arrive at the conclusion that through multiple procedures conflict can be transformed in a constructive way in order to provide and build an enabling environment for sustainable peace.

The alternative mechanism is hence best suitable to resolve conflicts in Africa. Africa has, and is still witnessing scores of violent conflicts. Such conflicts took different dimensions; including ethnic, religious, political and 
boundary issues, all of which have negatively impacted the development of the continent. Therefore, to tackle the scourge of conflicts in Africa, the alternative diplomatic mechanism which was applied successfully in the Nigeria - Cameroon case remains an essential tool for preventing, resolving and managing conflicts.

\section{REFERENCES}

Adedayo, A. 2013. "International Interventions and Peace building in Postcolonial Africa”, in Albert, I. O. and Eselebor, W.A. (eds), Managing Security in a Globalized World, Ibadan: John Archer.

Africa News Service. 2002. "Cameroon, Bakassi: Why the ICJ Judgment is Unacceptable-Government”; 24, October. Available in Lexis, News Library, All news File.

Agence France-Presse. 2002. Doc. FBIS-AFR-2002-1025

Aghemelo, A.T. and S. Ibhasebhor. 2006. "Colonialism as a Source of Boundary Dispute and Conflict among African States: The World Court Judgement on the Bakassi Peninsula and its Implications for Nigeria." Journal of Social Science I3 (3), pp. I77-I8I.

Akin, J. and E. Brahm. 2005. "Diplomacy”, Beyond Intractability. Eds, Guy Burgess and Heidi Burgess, Conflict Information Consortium. Boulder: University of Colorado.

Akinjide, R. I994. “Bakassi, Whose’ Bakassi?” West Africa News Magazine, April Edition.

Allee, T.L and P.K. Huth. 2006. "Legitimizing Dispute Settlement: International Legal Ruling as Domestic Cover”, American Political Science Review, Vol.1oo, No.2.

Anyu, J. Ndumbe. 2007. "The ICJ and Border-Conflict Resolution in Africa: The Bakassi Peninsula Conflict". Mediterranean Quarterly: A Journal of Global Issues, Volume I8 (3) Duke University Press.

Asobie, A. 2003. "Nigeria, Cameroon, and the Unending Conflict over Bakassi". Vanguard Nigerian Newspaper, 27 February.

Ate, B. E. I992. "Nigeria and Cameroun". in B.E. Ate and B.A. Akinterinwa (Eds.) Nigeria and its immediate Neighbours: Constraints and Prospects of Sub-Regional Security in the 199os. Lagos: Nigerian Institute of International Affairs.

Babatola, Jadesola.E.T. 20I2. "Nigeria-Cameroon Boundary Dispute: The Quest for Bakassi Peninsular". International Affairs and Global Strategy, Vol. 4. 
Baye, F.M. 20I0. "Implications of the Bakassi conflict resolution for Cameroon". Africa Journal on Conflict Resolution, Vol. Io, No. I

Bekker, P.H.F. 2003. "Land and Maritime boundary between Cameroon and Nigeria (Cameroon v. Nigeria: Equatorial Guinea intervening)". The American Journal of International Law 97 (2), pp 387-398.

Berridge, G.R. 2005. Diplomacy: Theory and Practice. New York: Palgrave Macmillan.

Borzello, A. 2004. "My Home is another Country". BBC News Report i9 January. Available from http://news.bbc.co.uk/pr/fr/-/hi/world Africa/340I407.stm

Brierly, J.L. I963. The Law of Nations: An Introduction to the International Law of Peace. Oxford: Clarendon Press.

Brownlie, I. 2009. "The Peaceful Settlement of International Disputes". Chinese Journal of International Law, Vol. 8. No. 2

Cameroon Television (CRTV) Online. 2002. "Nigeria Rejects ICJ Ruling; Cameroonians Urged to Continue to Live in Harmony with Nigerians". National News Round-up, 25 October. Available from, http:// wwwcrtv.cm/actualite_det.php?code $=592$.

Collier, J.G. I996. “The International Court of Justice and the Peaceful Settlement of Disputes". in Lowe, V, and M. Fitzmaurice (eds), Fifty Years of the ICJ: Essays in Honour of Sir Robert Jennings, Cambridge: University Press.

Dinkle, A. 20II. "Diplomacy - The Alternative Dispute Resolution of the Ancients”.Ezine@rticles

Eboh, C. 2005. "Nigeria-Cameroon fail to set new Bakassi pullout date". Washington Post Online I5 October.

Eze, O. 2007. "Nigeria and Cameroon Before the International Court of Justice". paper presented in the International Peace Institute Conference on the Pacific Settlement of Disputes, New York, I8, July.

Friends of the Earth. 2003. "Conflict, corruption and climate change: George Bush's new Oil agenda." Available from: www.oe.co.uk

Gambari, I.A. 2007. "Keynote Address" presented at the International Peace Institute (IPI) International Policy Conference on the Pacific Settlement of Border Disputes. New York, I8 July.

Lacey, M and N. Banerjee. 2002. "World Court Rules for Cameroon in prolonged oil-land border dispute with Nigeria". New York Times II, October. Available from: http://www.glbalpolicy.org/wldcourt/icj/2002/Ioribakassi.htm

Llamzon, A.P. 2008. "Jurisdiction and Compliance in recent decisions of 
the International Court of Justice" European Journal of International Law, Vol.I8, No. 5

Martin, L. 200I. British Documents on the End of Empire (Nigeria) Series B, Volume 7. London: Institute of Commonwealth Studies.

Mbuh, J.M. 2004. International Law and Conflicts: Resolving Border and Sovereignty Disputes in Africa. Yaounde: iUniverse Incorporated.

Menkel-Meadow, C. 20I2. "Introduction and Coda: International Dispute Resolution", in Carrie Menkel-Meadow (ed), Complex Dispute Resolution: Volume III. Farnham, UK: Ashgate.

Nowa, O. 2012. "The Bakassi Story”, Vanguard Nigerian Newspaper, 20, September.

Ntamark, G. 2002. "The League of Nations Mandate System with special reference to the Cameroons", Unpublished PhD Thesis, Keele University.

Nugent, W.V. I9I4. "The Geographical Results of the Nigeria-Kamerun Boundary Demarcation Commission”. Geographical Journal, pp.630-65I.

Odje, A.M. 2002. "ICJ Judgment on Bakassi: How enforceable?". Available from: < http:// www.nigerdeltacongress.com/iarticles/icj_judgment_on_bakassi.htm >.

Ofonagoro, W. 2013. “The Bakassi Sovereignty and International Politics”. Vanguard Nigerian Newspaper 3, April

Okoh, W.I. 2006. "Bakassi Belongs to Nigeria” THE SUN Nigerian Newspaper, I4 August.

Rupesinghe, K. I995. "Multi-Track Diplomacy: and the Sustainable Route to Conflict Resolution". CSQ Issue; Culture, Resources and Conflicts, Vol.ig, No.3.

Sumner, B.T. 2004. "Territorial Disputes at the International Court of Justice". Duke Law Journal, No. 53

The Guardian Nigerian Newspaper. 2002. I5 November.

The International Court of Justice Web site, www.icj-cij.org.

The Tide Online Nigerian Paper. 2006. "Nigeria, Cameroon reach Accord on Boundary". I7 January. Available at www.thetidenews.com

The Washington Times. 2006. I5 June

This Day Nigerian Newspaper. 2006. 'Now August 2008” I3, June

This Day Nigerian Newspaper. 2002. I5 November

U.N Press release. 2006. "Nigeria, Cameroon Sign Agreement ending Decades-ld border Dispute; Sets Procedures for Nigerian withdrawal 
from Bakassi Peninsula" AFR/ı397 I2 June

2002. "Nigeria Defends Defiance of World Court Border Ruling" SG/T/2344 Io September.

Vanguard Nigerian Newspaper. 2002. "UN Panel on Bakassi meets December I", 29, November.

Vinuales, J.E and D. Bentolila. 20I2. "The use of alternative (non-judicial) means to enforce investment awards". in Boisson de Chazournes,L., M. Kohen and J.E. Vinuales (eds) Diplomatic and Judicial means of Dispute Settlement: Assessing their interactions, The Hague: Brill.

\section{ABSTRACT}

This study focuses on the subject of the application of alternative means as a complement to the judicial, adjudication and arbitration options in the resolution of disputes/conflicts. The Nigeria-Cameroon conflict over Bakassi is used as a case in point. By blending the theoretical perspectives on the diplomacy/negotiation approach with the reality of this case it argues that the application of alternative dispute resolution mechanism, in this instance, facilitated a long lasting and negotiated settlement, which led to amicable and final resolution. With the understanding that dispute/conflict resolution seeks to find solutions acceptable to both parties to achieve peaceful coexistence, the question arises as to whether the ICJ's ruling in itself was able to amicably resolve the dispute? What we find is that the Ruling of 2002 did not in itself lead to instant settlement, rather it drew negative responses from Nigeria, so that it took the intervention of stakeholders in the international system, especially the Western countries, and particularly the UN and its then Secretary-General, Kofi Annan, to activate the UN machinery to put in place direct bilateral talks between Nigeria and Cameroon to iron out their differences. The emergent Mixed Commission and the Greentree Agreement of 2006 ensured the achievement of reconciliation, lasting peace and final resolution along the lines of the ICJ's Judgment of 2002.

\section{KEYWORDS}

Conflict; Nigeria; Cameroon; Resolution; Diplomatic; Alternative; Bakassi; ICJ.

Received on March 2, 2017. Approved on September 28, 2017. 